\title{
Enterprise Risk Management In Banking Industry
}

\author{
Christina Liem \\ Department Management, Faculty of Business, President University \\ Jl. Ki Hajar Dewantara, Kota Jababeka, Cikarang Baru, Bekasi 17550, Indonesia \\ E-mail: cliem@president.ac.id
}

\begin{abstract}
Enterprise Risk Management (ERM) in banking industry is a rare topic in academic research, even though ERM implementation becomes new regulation from the banking regulators since year 2014 . The purpose of this study is to examine ERM implementation during the early stage of the ERM implementation regulation in Indonesian, especially its impact towards bank performance and vice versa. This study focuses on all 4 (four) state-owned commercial banks in Indonesia though a descriptive explanatory study and data panel GLS simple regression by STATA MP-64. This study employs ERM Index (Gordon et al, 2009) as a proxy of ERM implementation; and bank performance is presented by 3 (three) proxies: NIM, ROAA, and EM. The findings show that $75 \%$ of state-owned commercial banks have positive ERM Index, and also, they have the different maturity stage of ERM implementation. Moreover, this study identifies that ERM Index has positive significant impact towards ROAA and vice versa; ERM Index has positive but insignificant impact towards NIM and vice versa; and ERM index has positive but insignificant impact towards EM. As a conclusion, this study proposes to all commercial banks in Indonesia should implement ERM seriously implement because it has been proven that ERM implementation delivers positive impact towards bank profitability and it transmits a positive signal to shareholders.
\end{abstract}

Keywords: Enterprise Risk Management; Banking Industry; State-owned Commercial Banks; Indonesia

\begin{abstract}
Abstrak
Topik penelitian tentang Enterprise Risk Management (ERM) di industry perbankan masih jarang, meskipun penerapan ERM menjadi regulasi baru dari Bank Indonesia sejak 2014. Tujuan dari studi ini adalah untuk menganalisa penerapan ERM pada masa awal regulasi tentang penerapan ERM di Indonesia, khususnya pengaruh ERM terhadap kinerja perbankan in Indonesia melalui studi esplanatori deskriptif dan data panel GLS regresi sederhana dengan menggunakan STATA MP-64. Studi ini menggunakan ERM Index (Gordon et al, 2009) sebagai proxy dari penerapan ERM; dan proxy kinerja bank menggunakan: NIM, ROAA, dan EM. Studi ini menemukan bahwa $75 \%$ dari bank komersial milik pemerintah mempunyai penerapan ERM yang positif, dan mereka juga mempunyai tingkat kedewasaan yang berbeda dalam menerapkan ERM. ERM Index memepuyai pengaruh positif dan siknifikan terhadap ROAA dan sebaliknya; selanjutnya ERM juga mempunyai pengaruh positif tetapi tidak siknifikan terhadap NIM dan EM. Sehingga bisa disimpulkan bahwa studi ini menyarankan semua bank komersial di Indonesia untuk menerapkan ERM secara serius karena sudah dibuktikan bahwa penerapan ERM memberikan pengaruh positif terhadap bank profitability, dan bisa memberikan tanda positif kepada pemegang saham.
\end{abstract}

Keywords: Enterprise Risk Management; Industri Perbankan; Bank Komersial milik pemerintah; Indonesia

\section{A. Introduction}

The main objective of financial management is to increase the firm value. Commonly, the firm value is measured by profitability ratios and/or share price (Keown et al, 2016). According to Capital Asset Pricing Model (CAPM), risk has no correlation with portfolios return in perfect market, where there is no expected return difference, no investment costs, and no information asymmetric (Sharpe, 1964; Lintner, 1965). Therefore, CAPM believes 
that risk under perfect market condition has no influence towards the firm value. In fact, there is no perfect market in reality; so, risk has impact on the firm value.

Managing risk is critical for the firm (Olson et al, 2008; Eckles et al, 2014) since risk management failure is one of the major triggers of the recent global financial crisis in 20072008. Some empirical studies show the evidence that risk management has positive impact towards the firm value (Allayanmis and Weston, 2001; Jin and Jorion, 2006).Traditionally, organizations have managed risks classified as key by using a Siloed approach where each area of the organization manages its own risks. Until the late 1970s, the firm risk management objective is to reduce losses related with pure risk through insurance (McShane, 2015). Stulz (1996) argues that risk management benefits the firm value by reducing the unpredictability of cash flows and the potential costs of bankruptcy, by reducing the cost of capital, and by reducing taxes.

Then, there has been a remarkable change in the role of risk management in the firms; which is from ambiguous ownership of some types of risk to all risks assigned ownership with accountability; that recently known as Enterprise Risk Management (ERM) (Power, 2004; Nocco and Stulz, 2006). Originally, the ERM conceptual framework is proposed by COSO (2004) and focusing on non-financial institutions.

ERM is a process, affected by an entity's board of directors, management and other personnel, applied in a strategy setting and across the enterprise, designed to identify potential events that may affect the entity, and manage risk to be within its risk appetite, to provide reasonable assurance regarding the achievement of entity objectives (COSO, 2004).

Moreover, Hyot et al (2011) mention that ERM has been the topic of increased media attention in recent years. ERM has become gradually relevant in recent years, as a result of complexity of risks and the further development of regulatory frameworks (Lechner and Gatzert, 2017). ERM frameworks by COSO (2004) has potential to enhance the firm performance (Power, 2009); and some practitioners who have implementing ERM experience increment in their firm performance (Sobel and Reding, 2004). In practice, the implementation of ERM is able to boost stakeholders' confidence. However, academic literature contributes poorly to address the impact of ERM implementation towards the firm performance (Arena and Arnaboldi, 2014), especially in banking industry.

Furthermore, as one of quantitative technique in order to examine ERM implementation; Gordon et al (2009) formulate ERM Index based on the four risk management objectives (COSO, 2004), which are:

- Strategy - high-level goals, aligned with and supporting the organization's mission

- Operations - effective and efficient use of resources

- Financial Reporting - reliability of operational and financial reporting

- Compliance - compliance with applicable laws and regulations

Previous studies of ERM implementation impact towards firm performance have inconsistency results. Gordon et al (2009) find the positive impact of ERM implementation towards the non-financial institutions' performance, where ERM implementation variable is represented by ERM Index.

On the other hand, Pagach and Warr (2010) employ Chief Risk Officer (CRO) appointment as ERM implementation variable in banking industry, and show ERM 
implementation is fail to support the bank performance, even though it is proven to reduce earnings volatility. Therefore, this study focuses on ERM implementation that represented by ERM Index (Gordon et al, 2009) in banking industry and its impact towards the bank performance and vice versa.

\section{B. Literature Study \\ ERM}

The previous studies of ERM implementation deliver inconsistency impacts towards the firm performance. These inconsistency findings indicate that ERM implementation still looking for generalisation conceptual framework across nations in specific industry. Some previous studies prove that ERM implementation has positive impact towards the firm performance. Gordon et al (2009) study about ERM and firm performance with 112 ERM implemented firms as the unit analysis.

This study views ERM through the effect of contingency view and the result shows that ERM has positive impacts towards the firm performance. Hoyt et al (2011) focus on the correlation between ERM and the firm performance on 275 insurance firms, and the result shows that ERM implementation has positive impact towards firm performance. Moreover, De Souza et al (2012) analyse ERM influence on the firm performance improvement of 500 Brazillian non-financial firms. Their study finds that the maturity of ERM implementation was the important factor to increase the firm performance. Moreover, McShane et al (2011) find that risk management (whether traditional risk management or ERM) has positive correlation with the firm performance. However, their study does not find any improvement on the firm performance for those who applied ERM instead of traditional risk management. In other words, ERM has no correlation with the firm performance improvement. Their study focus on 82 public listed US financial firms in year 2008.

The measurement tools of ERM implementation in a firm are CRO appointment (Aebi et al, 2012; Waweru and Kisaka, 2011; Liebenberg and Hyot, 2003; Lundqvist, 2015), and ERM Index (Gordon et al, 2009). ERM Index this study adopts from Gordon et al (2009) with detail equation as follows:

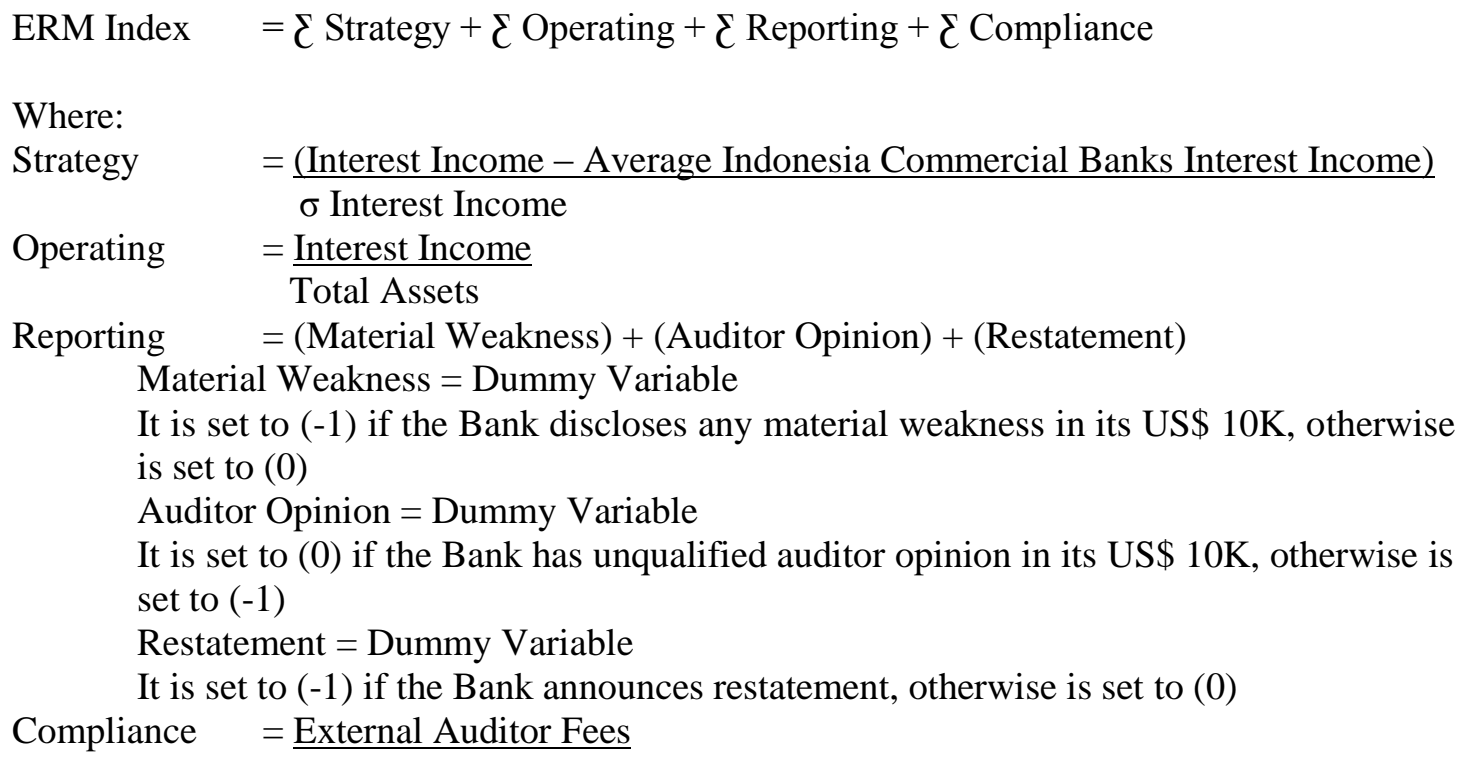


In banking industry, CRO appointment is to identify if the firm is currently undertaking an ERM program. Since all the banks in Indonesia must implement ERM since 2014 in order to comply with Indonesian Financial Services Authority (FSA) regulation establishment (No.17/ POJK.03/2014) then continuing with FSA Circular Letter No.14/SEOJK.03/2015 regarding ERM implementation in banking sector; therefore, this study eliminate CRO appointment and utilizing ERM Index by Gordon et al (2009) as a solo ERM Implementation proxy in this study.

\section{Bank Performance}

There are 3 common bank performance measurements, which are Net Interest Margin (NIM), Return on Average Asset (ROAA) and Equity Multiplier (EM). NIM is defined as the percentage of net interest revenue divided by total assets (Liang et al, 2013). NIM indicates bank's sensitivity and elasticity towards interest rate risk (Fathi et al, 2012).

ROAA is a measure of bank performance. Return on assets is the net profit after tax divided by total assets and indicates the returns generated from the assets financed by the bank (Kosmidou, 2008). This ratio measures income generated by the average assets financed by the bank in average (Bouzgarrou et al, 2017).

EM or well-known as DuPont model is the ratio of total asset divided by total equity capital (Sounders and Liliana, 2000). Through DuPont model, higher EM leads to higher ROE. It means higher EM means the Bank prefer to use equity rather than debt financing. Moreover, the EM ratio could predict the financial needs and the capital structure of the bank (Almazari, 2012). This study will analyse the impact of ERM implementation towards bank's performance that will be focusing on NIM, ROA, and EM; and vice versa.

\section{Research Methodology}

\section{Data}

This study focusing to analyse all 4 (four) state-owned commercial banks in Indonesia:

\section{- Bank Mandiri (BM)}

BM was established on October $2^{\text {nd }}, 1998$ as part of the bank restructuring program of 4 (four) state-owned commercial banks, which are Bank Bumi Daya, Bank Dagang Negara, Bank Exim, and Bapindo due to Asia financial crisis (1997-1998). BM focuses on 5 (five) key segments: corporate, commercial, micro, retail, and consumer finance. The BM vision is to be Indonesian most admired and progressive financial institution. Furthermore, BM aims to be the top 5 (five) banks in ASEAN in 2020.

\section{- Bank Negara Indonesia (BNI)}

BNI was established on July $5^{\text {th }}, 1946$ as the first state-owned bank that was established after the independence of Indonesia on August $17^{\text {th }}, 1945$. BNI was the first Indonesian Central Bank and commercial bank (1946-1955). BNI also printed Oeang Republik Indonesia or ORI as the first official method of payment (IDR) on October $30^{\text {th }}, 1946$. Then, in 1955, BNI has operating exclusively as commercial bank. In the beginning, BNI focuses on women and children as the key segments. BNI implemented women only bank 
employees and educate the children to have savings habit. Moreover, since 1963, BNI has pioneered banking services in universities. BNI vision is to be a leading bank that excels in services and performance.

\section{- Bank Rakyat Indonesia (BRI)}

BRI was established on December $16^{\text {th }}, 1895$ by Raden Bei Aria Wirjaadmadja as De Poerwokertosche Hulp en Spaarbank der Inlandsche Hoofden (Help and Savings Bank of the Aristocrats of Purwokerto). After long history of changing names (Bank Rakyat Indonesia Serikat, 1948; Bank Koperasi Tani dan Nelayan, 1960; Bank Negara Indonesia UrusanKoperasi, Tani, Nelayan, 1965; Bank Negara Indonesia for Rural Sector, 1968), finally in 2003, the Indonesian government gave the name of BRI. BRI vision is to be a leading commercial bank which always puts priority on customer satisfaction.

\section{- Bank Tabungan Negara (BTN)}

BTN was established in 1897 as Postpaarbank; in 1950 became Bank Tabungan Pos and finally in 1963, it changed become Bank Tabungan Negara in 1963. The, since 2002, BTN has focusing on mortgage. BTN vision is to be a leading bank in housing finance.

Those banks represent Indonesian all state-owned commercial banks with different market segments. Moreover, this study focuses on the ERM implementation impact towards bank performance and vice versa in the beginning of ERM implementation regulation from FSA during year 2014-2015. This study uses secondary data that has been generated from BankScope and its audited annual report year 2014 and 2015.

\section{Methodology}

The main research question of this study is: 'Does ERM implementation have significant impact towards bank performance and vice versa?' Therefore, in order to answer that research question, this study will focus on 3 (three) steps. Firstly, this study analyse ERM implementation through ERM Index (Gordon et al, 2009) examination of each state-owned commercial bank and presents the results as a descriptive explanatory study.

After that, this study investigates bank performance through 3 (three) proxies: NIM (Fathi et al, 2012; Ling et al, 2013), ROAA (Kosmidou, 2008; Bouzgarrou et al, 2017), and EM (Sounders, 2000; Almazari, 2012); and the results also be presented as a descriptive explanatory study. Finally, this study examines the impact of ERM implementation towards bank's performance and vice versa through the following research framework:

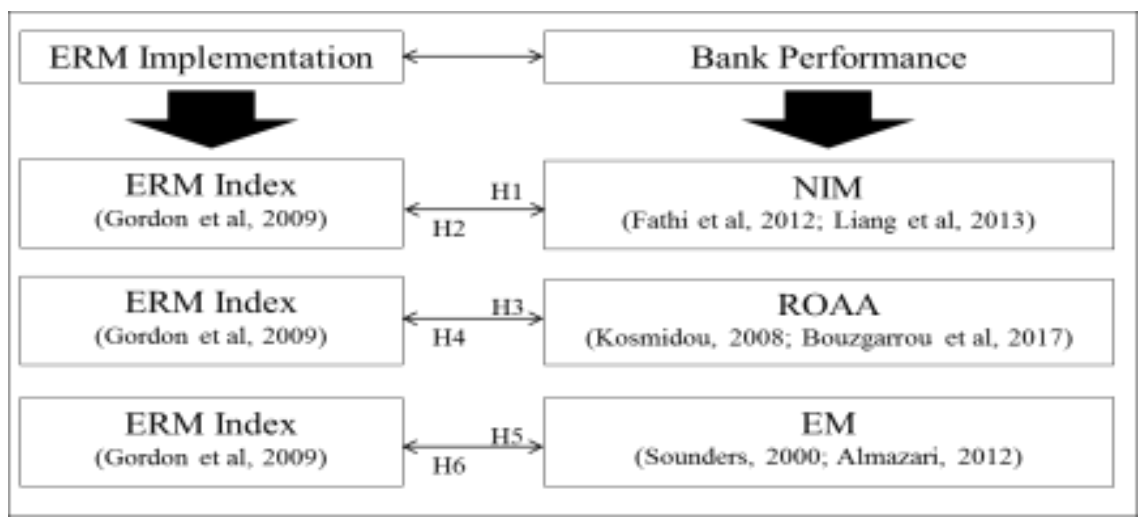

Picture 1: Research Framework 
This study emphasises on 6 (six) hypotheses to examine the impact of ERM implementation towards bank performance and vice versa.

H1: ERM Index has significant impact towards NIM

H2: NIM has significant impact towards ERM Index

H3: ERM Index has significant impact towards ROAA

H4: ROAA has significant impact towards ERM Index

H5: ERM Index has significant impact towards EM

H6: EM has significant impact towards ERM Index

After that, this study will analyse whether the data behaviour is random effect or fixed effect through the data panel GLS regression result by STATA MP-64.

\section{E. Results and Discussion}

\section{ERM Index}

All 4 (four) state-owned commercial banks in Indonesia state that they have specific division to implement ERM, therefore it could be identified as they have CRO appointment as the other proxy of ERM implementation (Liebenberg and Hyot, 2003; Aebi et al, 2011; Waweru and Kisaka, 2011; Lundqvist, 2015). This study focuses on ERM Index to examine the ERM implementation of each state-owned commercial bank in Indonesia (Gordon et al, 2009).

Gordon et al (2009) examine the ERM implementation through ERM Index that contain of strategy, operating, reporting and compliance activities with adoption of the original ERM framework by COSO (2004). BRI has the highest ERM Index with average 5.0499. It means in the early stage of ERM implement regulation in Indonesia (year year 2014-2015).

BRI has reached the most mature ERM implementation among other state-owned commercial banks in Indonesia. However, BRI has been identified as the poor rank in compliance; where the compliance equation is external auditor fees divided by total assets (Gordon et al, 2009). Meanwhile, BNI has recorded as the highest rank in compliance, but BNI only reach the $3^{\text {rd }}$ rank in ERM Index. The detail calculation results are presented as table 1 below.

This study is questioning the fitness strategy equation by Gordon et al (2009) for those all 4 (four) state-owned commercial banks in Indonesia, since they have different key segments that lead to different business strategy. Is that appropriate to compare the interest income while each bank has different focus of market segment - for example a comparison between BRI with BM? BRI has focus on banking for SMEs while BM focuses on corporations as their market segment. This study suspects it should be different measurements for those commercial banks with different market segments, even though this study is not answering this issue. 
Table 1: ERM Index (year 2014-2015)

\begin{tabular}{|c|c|c|c|c|c|c|c|c|}
\hline \multirow{2}{*}{ Bank Name } & \multicolumn{4}{|c|}{ Strategy } & \multicolumn{4}{|c|}{ Operating } \\
\hline & 2014 & 2015 & Average & Rank & 2014 & 2015 & Average & Rank \\
\hline 1 BM & 4.6182 & 4.5703 & 4.5942 & 2 & 0.0242 & 0.0232 & 0.0237 & 2 \\
\hline \begin{tabular}{l|l|}
2 & BRI \\
\end{tabular} & 5.4722 & 5.5522 & 5.5122 & 1 & 0.0302 & 0.0289 & 0.0296 & 1 \\
\hline \begin{tabular}{l|l|}
3 & $\mathrm{BNI}$ \\
\end{tabular} & 2.2688 & 1.8008 & 2.0348 & 3 & 0.0260 & 0.0180 & 0.0220 & 3 \\
\hline \begin{tabular}{l|l|}
4 & BTN \\
\end{tabular} & -0.0468 & 0.1200 & 0.0366 & 4 & 0.0079 & 0.0108 & 0.0093 & 4 \\
\hline Average & 3.0781 & 3.0108 & 3.0445 & & 0.0221 & 0.0202 & 0.0212 & \\
\hline Maximum & 5.4722 & 5.5522 & 5.5122 & & 0.0302 & 0.0289 & 0.0296 & \\
\hline Minimum & -0.0468 & 0.1200 & 0.0366 & & 0.0079 & 0.0108 & 0.0093 & \\
\hline Mean & 3.4435 & 3.1855 & 3.3145 & & 0.0251 & 0.0206 & 0.0228 & \\
\hline \multirow{2}{*}{ Bank Name } & \multicolumn{4}{|c|}{ Reporting } & \multicolumn{4}{|c|}{ Compliance } \\
\hline & 2014 & 2015 & Average & Rank & 2014 & 2015 & Average & Rank \\
\hline \begin{tabular}{l|l}
1 & $\mathrm{BM}$ \\
\end{tabular} & 0.000 & 0.000 & 0.000 & 1 & 0.0097 & 0.0081 & 0.0089 & 3 \\
\hline \begin{tabular}{l|l|}
2 & BRI \\
\end{tabular} & 0.000 & -1.000 & -0.500 & 2 & 0.0084 & 0.0079 & 0.0082 & 4 \\
\hline \begin{tabular}{l|l|}
3 & $\mathrm{BNI}$ \\
\end{tabular} & 0.000 & -1.000 & -0.500 & 2 & 0.0264 & 0.0141 & 0.0203 & 1 \\
\hline \begin{tabular}{l|l|}
4 & BTN \\
\end{tabular} & -1.000 & -1.000 & -1.000 & 3 & 0.0122 & 0.0114 & 0.0118 & 2 \\
\hline Average & -0.250 & -0.750 & -0.500 & & 0.0142 & 0.0104 & 0.0123 & \\
\hline Maximum & 0.000 & 0.000 & 0.000 & & 0.0264 & 0.0141 & 0.0203 & \\
\hline Minimum & -1.000 & -1.000 & -1.000 & & 0.0084 & 0.0079 & 0.0082 & \\
\hline Mean & 0.000 & -1.000 & -0.500 & & 0.0110 & 0.0098 & 0.0104 & \\
\hline \multirow{2}{*}{ Bank Name } & \multicolumn{4}{|c|}{ ERM Index } & & & & \\
\hline & 2014 & 2015 & Average & Rank & & & & \\
\hline \begin{tabular}{l|l}
1 & $\mathrm{BM}$ \\
\end{tabular} & 4.6520 & 4.6016 & 4.6268 & 2 & & & & \\
\hline \begin{tabular}{l|l|}
2 & BRI \\
\end{tabular} & 5.5109 & 4.5890 & 5.0499 & 1 & & & & \\
\hline \begin{tabular}{l|l|}
3 & $\mathrm{BNI}$ \\
\end{tabular} & 2.3212 & 0.8328 & 1.5770 & 3 & & & & \\
\hline \begin{tabular}{l|l|}
4 & BTN \\
\end{tabular} & -1.0266 & -0.8578 & -0.9422 & 4 & & & & \\
\hline Average & 2.8644 & 2.2914 & 2.5779 & & & & & \\
\hline Maximum & 5.5109 & 4.6016 & 5.0562 & & & & & \\
\hline Minimum & -1.0266 & -0.8578 & -0.9422 & & & & & \\
\hline Mean & 3.4866 & 2.7109 & 3.0988 & & & & & \\
\hline
\end{tabular}

\section{Bank Performance}

This study highlights the excellence of BRI profitability performance with 7.9485 in NIM and 3.2085 in ROAA; and achieves the $1^{\text {st }}$ rank during the early stage of ERM implement regulation in the Indonesian banking industry during year 2014-2015. This result shows consistency with the key segments of BRI, which is SMEs. SMEs provide higher NIM compares with big corporation NIM. Therefore, it is understandable that BM has less NIM compared with BRI.

On contrary, BTN that focusing on public mortgage as government agent to distribute subsidise mortgage for Indonesian, especially for those who buy their first house. Consequently, BTN still the best options for Indonesian citizens to apply for mortgage because government subsidise interest rate for mortgage only has been distributing through BTN; despite of the lowest rank of NIM and ROAA. BTN has the highest EM ratio among other state-owned commercial banks in Indonesia; it indicates that BTN has the highest ROE which is positive signal for shareholders.

Table 2: Bank Performance (year 2014-2015) 


\begin{tabular}{|c|c|c|c|c|c|c|c|c|}
\hline \multirow{2}{*}{ Bank Name } & \multicolumn{4}{|c|}{ NIM } & \multicolumn{4}{|c|}{ ROAA } \\
\hline & 2014 & 2015 & Average & Rank & 2014 & 2015 & Average & Rank \\
\hline $1 \mathrm{BM}$ & 5.5890 & 6.0570 & 5.8230 & 3 & 2.6010 & 2.3970 & 2.4990 & 2 \\
\hline \begin{tabular}{|l|l|}
2 & BRI \\
\end{tabular} & 7.9410 & 7.9560 & 7.9485 & 1 & 3.3930 & 3.0240 & 3.2085 & 1 \\
\hline \begin{tabular}{|l|l|}
3 & BNI \\
\end{tabular} & 6.3180 & 6.5680 & 6.4430 & 2 & 2.6960 & 1.9760 & 2.3360 & 3 \\
\hline \begin{tabular}{|l|l|}
4 & BTN \\
\end{tabular} & 4.2420 & 4.7700 & 4.5060 & 4 & 0.8310 & 1.1700 & 1.0005 & 4 \\
\hline Average & 6.0225 & 6.3378 & & & 2.3803 & 2.1418 & & \\
\hline Maximum & 7.9410 & 7.9560 & & & 3.3930 & 3.0240 & & \\
\hline Minimum & 4.2420 & 4.7700 & & & 0.8310 & 1.1700 & & \\
\hline Mean & 5.9535 & 6.3125 & & & 2.6485 & 2.1865 & & \\
\hline \multirow{2}{*}{ Bank Name } & \multicolumn{4}{|c|}{ Equity Multiplier } & & & & \\
\hline & 2014 & 2015 & Average & Rank & & & & \\
\hline $1 \mathrm{BM}$ & 8.1553 & 7.6161 & 7.8857 & 3 & & & & \\
\hline \begin{tabular}{|l|l|}
2 & BRI \\
\end{tabular} & 8.2082 & 7.7649 & 7.9865 & 2 & & & & \\
\hline \begin{tabular}{|l|l|}
3 & $\mathrm{BNI}$ \\
\end{tabular} & 6.8267 & 6.4840 & 6.6554 & 4 & & & & \\
\hline \begin{tabular}{l|l|}
4 & BTN \\
\end{tabular} & 11.7999 & 12.3958 & 12.0978 & 1 & & & & \\
\hline Average & 8.7475 & 8.5652 & & & & & & \\
\hline Maximum & 11.7999 & 12.3958 & & & & & & \\
\hline Minimum & 6.8267 & 6.4840 & & & & & & \\
\hline Mean & 8.1817 & 7.6905 & & & & & & \\
\hline
\end{tabular}

Interestingly,

BNI as a pioneer commercial bank in Indonesia that has strong intention in education successfully to reach $2^{\text {nd }}$ rank in NIM, and $3^{\text {rd }}$ rank in ROAA during year 2014-2015. It shows that education market segment provide higher NIM compares with big corporations, because BM with big corporation as their main market segment has produce less NIM compares with BNI. However, BNI shows the lowest EM ratio during year 2014-2015 among other state-owned commercial banks in Indonesia. It represents that BNI has the lowest ROE which forward a negative signal to the shareholders.

Additionally, this study identifies that each of state-owned commercial bank in Indonesia has different market segment, even though all of them are the Indonesia government's main partners to distribute financial support for the Indonesian citizens through subsidise interest rate, such as for SMEs (BRI) and mortgage (BTN). Meanwhile for BM, all state-owned enterprises (SOEs) have primary banking activities with BM. Finally, BNI is the main engine for government to educate Indonesian citizens in order to increase Indonesian financial literacy level.

Thus, bank performance measurements of all 4 (four) state-owned commercial banks should include how effective and efficient their support to the government in order to bring benefits to Indonesian citizens, even though this study would not focuses to analyse the support measurements of all 4 (four) state-owned commercial banks to the Indonesian government.

\section{Statistics Results}

This study examines the impact of ERM implementation towards bank performance and vice versa, that describes into 6 (six) hypotheses with detail discussion as follows: 


\section{ERM Index and NIM}

ERM Index as the sole proxy that represents ERM implementation, while NIM as one of bank performance proxy.

H1: ERM Index has significant impact towards NIM

The simple regression equation is: $\mathrm{y}=5.7860+0.1529 \mathrm{ERM}$ Index $+\mathrm{e}$

$\mathrm{P}>|\mathrm{z}|=0.4000$ (insignificant)

$\mathrm{R}$-sq overall $=0.5506$

Random-effects GLS regression

H1 rejected, because ERM Index has positive impact but insignificant towards NIM

H2: NIM has significant impact towards ERM Index

The simple regression equation is: $\mathrm{y}=-2.7390+0.8603 \mathrm{NIM}+\mathrm{e}$

$\mathrm{P}>|\mathrm{z}|=0.2700$ (insignificant)

R-sq overall $=0.5506$

Random-effects GLS regression

H2 rejected, because NIM has positive impact but insignificant towards ERM Index

The data panel GLS simple regression shows that ERM Index has positive impact towards NIM even though insignificant and vice versa. Even though $\mathrm{H} 1$ and $\mathrm{H} 2$ are rejected, but since this simple regression R-sq is $55.06 \%$ and it is random effect, therefore this result could be considered as a general prediction that ERM implementation has positive impact towards NIM in commercial banking Industry in Indonesia. This simple regression results support previous studies completed by Gordon et al (2009), McShane et al (2011), and Hoyt et al (2011) that mention if ERM has positive impact towards bank performance, even though insignificant.

\section{ERM Index and ROAA}

The following hypothesis examine the impact of ERM Index towards ROAA and vice versa; while ERM Index still represents ERM implementation and ROAA represents the bank performance proxy.

H3: ERM Index has significant impact towards ROAA

The simple regression equation is: $\mathrm{y}=1.2954+0.3746$ ERM Index $+\mathrm{e}$

$\mathrm{P}>|\mathrm{z}|=0.0000$ (significant)

$\mathrm{R}$-sq overall $=0.8490$

Random-effects GLS regression

H3 accepted, because ERM Index has positive and significant impact towards ROAA

H4: ROAA has significant impact towards ERM Index

The simple regression equation is: $\mathrm{y}=-1.9892+2.020 \mathrm{ROAA}+\mathrm{e}$

$\mathrm{P}>|\mathrm{z}|=0.0000$ (significant)

$\mathrm{R}$-sq overall $=0.8490$

Random-effects GLS regression

H4 accepted, because ROAA has positive and significant impact towards ERM Index 
Through this simple regression, this study finds that ERM Index has positive and significant impact towards ROAA and vice versa. Therefore, this study accepts H3 and H4; and strengthens previous studies' findings that ERM implementation has positive impact towards bank performance from Gordon et al (2009), McShane et al (2011), and Hoyt et al (2011).

Moreover, this study suggests all commercial banks in Indonesia to implement ERM seriously rather than just to accomplish the FSA regulation, because ERM implementation is proven has significant positive impact towards ROAA or bank profitability as one of the bank performance measurement.

\section{ERM Index and EM}

The following hypothesis examine the impact of ERM Index towards EM and vice versa; while ERM Index still represents ERM implementation and EM as one of the proxies of bank performance.

H5: ERM Index has significant impact towards EM

The simple regression equation is: $\mathrm{y}=8.3614+0.1144$ ERM Index $+\mathrm{e}$

$\mathrm{P}>|\mathrm{z}|=0.6560$ (insignificant)

R-sq overall $=0.4083$

Random-effects GLS regression

H5 rejected, because ERM Index has positive but insignificant impact towards EM

H6: EM has significant impact towards ERM Index

The simple regression equation is: $\mathrm{y}=3.4850-0.1048 \mathrm{EM}+\mathrm{e}$

$\mathrm{P}>|\mathrm{z}|=0.8580$ (insignificant)

R-sq overall $=0.4083$

Random-effects GLS regression

H6 rejected, because EM has negative and insignificant impact towards ERM Index

This study rejects H5 and H6 due to insignificant impact of ERM Index towards EM and vice versa. EM measures the capital structure management ability of the Bank; the higher EM potentially leads to higher ROE.

Corresponding to H5, ERM Index has positive impact even though insignificant towards EM; and subsequently this simple regression result is consistent with the previous studies findings by Gordon et al (2009), McShane et al (2011), and Hoyt et al (2011) that show ERM implementation has positive impact towards bank performance. Moreover, this study also rejects H6, which shows the EM has negative and insignificant impact towards ERM Index. It means the higher EM ratio leads to lower ERM Index.

This study indicates that the Bank has serious challenge to manage capital structure balance in order to deliver the most efficiency composition between equity and debt financing.

\section{F. Conclusion and Recommendation}

The main research question of this study is: 'Does ERM implementation have significant impact towards bank's performance and vice versa?' In order to answer the main research question, this study examines the impact of ERM Index as a solo proxy of ERM 
implementation; towards the 3 (three) proxies: NIM, ROAA, and EM as represents bank performance and vice versa. Therefore, this study employs 6 (six) hypotheses as follows:

\section{H1: ERM Index has significant impact towards NIM}

H1 rejected, because ERM Index has positive impact but insignificant towards NIM H2: NIM has significant impact towards ERM Index

H2 rejected, because NIM has positive impact but insignificant towards ERM Index H3: ERM Index has significant impact towards ROAA

H3 accepted, because ERM Index has positive and significant impact towards ROAA H4: ROAA has significant impact towards ERM Index

H4 accepted, because ROAA has positive and significant impact towards ERM Index H5: ERM Index has significant impact towards EM

H5 rejected, because ERM Index has positive but insignificant impact towards EM H6: EM has significant impact towards ERM Index

H6 rejected, because EM has negative and insignificant impact towards ERM Index

ERM Index is proven has positive significant impact towards ROAA and vice versa. It shows that ERM implementation is significant to increase ROAA as a crucial profitability measurement. Moreover, ERM Index has positive impact towards NIM, even though insignificantly and vice versa. Since NIM is bank's specific profitability measurement; therefore, this study confirms that ERM implementation has positive impact towards bank profitability ratios as important measurement of bank performance and vice versa in early stage of ERM implementation regulation during year 2014-2015.

In addition, this study indicates positive insignificant impact of ERM Index towards EM. It means better ERM implementation forward positive signal to shareholders and it is important for the public listed banks in Indonesia. This study concludes that all commercial banks in Indonesia should seriously implement ERM because it is proven deliver positive impact towards bank profitability and it transmits a positive signal to shareholders.

As conclusion of this study that concentrating to examine ERM implementation impact towards bank performance and vice versa in the early stage of ERM implementation regulation during year 2014-2015 in all 4 (four) state-owned commercial banks in Indonesia confirms that all the Bank complies with the FSA regulation through develop ERM division in each state-owned commercial Bank. Furthermore, the ERM Index shows 3 (three) out 4 (four) state-owned commercial banks has positive ERM Index in the early stage of ERM implementation regulation, and it also indicates the different maturity stage of ERM implementation. From the data of ERM Index, it shows that BRI reach the most maturity level of ERM Implementation, following by BM, BNI and BTN in the early stage of ERM implementation regulation by FSA.

Finally, this study recommends future study to explore deeply about unsettled questions that discovers from this study: the ERM index measurement for strategy in commercial banking industry if the banks have different market segment. The argumentation is a common if different market segment leads to different business strategy; therefore, it inappropriate if ERM Index implement same measurement to examine each commercial bank's strategy.

Also, this study propose to monitoring ERM implementation of all 4 (four) state-owned commercial banks in Indonesia in different stage after ERM implementation regulation has 
established in year 2014-2015. This longitudinal study is needed to measure the growth of ERM implementation maturity of each state-owned commercial bank and discover the factors that significantly influencing the growth of ERM implementation maturity.

This is important for Indonesian commercial banking industry, since this study confirms that ERM implementation has positive impact towards bank performance and these findings consistent with previous studies has been done by Gordon et al (2009), McShane et al (2011), and Hoyt et al (2011).

\section{G. References}

BNI. (2014). Annual Report. Jakarta: Bank Negara Indonesia. BNI. (2015). Annual Report. Jakarta: Bank Negara Indonesia. BRI. (2014). Annual Report. Jakarta: Bank Rakyat Indonesia. BRI. (2015). Annual Report. Jakarta: Bank Rakyat Indonesia. BTN. (2014). Annual Report. Jakarta: Bank Tabungan Negara. BTN. (2015). Annual Report. Jakarta: Bank Tabungan Negara. Mandiri, B. (2014). Annual Report. Jakarta: Bank Mandiri. Mandiri, B. (2015). Annual Report. Jakarta: Bank Mandiri.

Aebi, V., Sabato, G., \& Schmid, M. (2012). Risk management, corporate governance, and bank performance in the financial crisis. Journal of Banking \& Finance, 36(12), 3213-3226.

Allayannis, G., \& Weston, J. P. (2001). The use of foreign currency derivatives and firm market value. The review of financial studies, 14(1), 243-276

Almazari, A. A. (2012). Financial performance analysis of the Jordanian Arab bank by using the DuPont system of financial analysis. International Journal of Economics and Finance, 4(4), 86.

Arena, M., \& Arnaboldi, M. (2014). Risk and performance management: are they easy partners?. Management Research Review, 37(2), 152-166.

Bouzgarrou, H., Jouida, S., \& Louhichi, W. (2017). Bank profitability during and before the financial crisis: Domestic vs. foreign banks. Research in International Business and Finance.

Committee of Sponsoring Organizations of the Treadway Commission. (2004). The (COSO).(2004). Enterprise risk management-integrated framework.

Eckles, D. L., Hoyt, R. E., \& Miller, S. M. (2014). Reprint of: The impact of enterprise risk management on the marginal cost of reducing risk: Evidence from the insurance industry. Journal of Banking \& Finance, 49, 409-423.

Fathi, S., Zarei, F., \& Esfahani, S. S. (2012). Studying the role of financial risk management on return on equity. International Journal of Business and Management, 7(9), 215.

Gordon, L.A., Loeb, M.P., Tseng, C.-Y., 2009. Enterprise risk management and firm performance: a contingency perspective. Journal of Accounting and Public Policy 28, 301-327.

Hoyt, R.E., Liebenberg, A.P., 2011. The value of enterprise risk management. Journal of Risk and Insurance 78 (4), $795 \mathrm{e} 822$.

Jin, Y., \& Jorion, P. (2006). Firm value and hedging: Evidence from US oil and gas producers. The Journal of Finance, 61(2), 893-919.

Kosmidou, K., \& Zopounidis, C. (2008). Measurement of bank performance in Greece. South-Eastern Europe Journal of Economics, 1(1), 79-95.

Lechner, P., \& Gatzert, N. (2017). Determinants and value of enterprise risk management: empirical evidence from Germany. The European Journal of Finance, 1-27.

Liang, Q., Xu, P., \& Jiraporn, P. (2013). Board characteristics and Chinese bank performance. Journal of Banking \& Finance, 37(8), 2953-2968.

Liebenberg, A. P., \& Hoyt, R. E. (2003). The determinants of enterprise risk management: Evidence from the appointment of chief risk officers. Risk Management and Insurance Review, 6(1), $37-52$. 
Lintner, J. (1965). The valuation of risky assets and the selection of risky investments in the portfolios and capital budgets, Review of Economics and Statistics 47, 13-37.

Lundquist, A. E. (2015). Enterprise Risk Management (ERM) at US colleges and universities: Administration processes regarding the adoption, implementation, and integration of ERM. Western Michigan University.

Martin, T. K. (2014). Financial Management Principles and Applications (Vol. 12). Edinburgh Gate: Pearson New International Edition.

McShane, M. K., Nair, A., \& Rustambekov, E. (2011). Does enterprise risk management increase firm value?. Journal of Accounting, Auditing \& Finance, 26(4), 641-658.

Nocco, B. W., \& Stulz, R. M. (2006). Enterprise risk management: Theory and practice. Journal of applied corporate finance, 18(4), 8-20.

Olson, D. L., \& Dash Wu, D. (2010). A review of enterprise risk management in supply chain. Kybernetes, 39(5), 694-706.

Pagach, D., \& Warr, R. (2010). The effects of enterprise risk management on firm performance.

Power, M. (2004). The risk management of everything. The Journal of Risk Finance, 5(3), 58-65.

Power, M. (2009). The risk management of nothing. Accounting, organizations and society, 34(6-7), 849-855

Sharpe, W. (1964). Capital asset prices: A theory of market equilibrium under conditions of risk, Journal of Finance, 19, 425-442.

Silva De Souza, R., Da Silva Gomes, S. M., Leal Bruni, A., Garcia De Oliveira, G., Santos Sampaio, M., \& Almeida De Faria, J. (2012). Enterprise Risk Management and Performance Improvement: A Study with Brazilian Nonfinancial Firms. In Performance Measurement and Management Control: Global Issues (pp. 275-298). Emerald Group Publishing Limited.

Sobel, P. J., \& Reding, K. F. (2004). Aligning corporate governance with enterprise risk management: melding enterprise risk management with governance means directors, senior management, internal and external auditors, and risk owners must work interdependently. Management Accounting Quarterly, 5(2), 29.

Sounders, A. \& S. Liliana. (2000). The determinants of bank interest rate margins: An international study. Journal of International Money and Finance, 19: 813-83.

Stulz, R. M. (1996). Rethinking risk management. Journal of applied corporate finance, 9(3), 8-25.

Waweru, N., \& Kisaka, E. S. (2011). The Effect of Enterprise Risk Management Implementation on the Value of Companies Listed in the Nairobi Stock Exchange. 